Egyptian Journal of Aquatic Biology \& Fisheries

Zoology Department, Faculty of Science,

Ain Shams University, Cairo, Egypt.

ISSN $1110-6131$

Vol. 25(2): 465 - 485 (2021)

www.ejabf.journals.ekb.eg

\title{
Effect of Aflatoxin B1 on farmed Cyprinus carpio in conjunction with bacterial infection
}

\author{
Ahmed H. Sherif ${ }^{1 *}$, Abeer M. Elshenawy ${ }^{2}$, Ayman A. Attia $^{3}$, Soad S. A. Salama $^{4}$ \\ ${ }^{1}$ Fish Diseases Department, Animal Health Research Institute AHRI, Agriculture Research Centre ARC, Kafr- \\ Elsheikh, 12619, Egypt \\ ${ }^{2}$ Biochemistry unit.Nutritional difeciency diseases and toxicology Department, Animal Health \\ Research Institute AHRI, Agriculture Research Centre ARC, Kafr-Elsheikh, Egypt \\ ${ }^{3}$ Pathology Department, Animal Health Research Institute AHRI, Agriculture Research Centre ARC, Kafr- \\ Elsheikh, Egypt \\ ${ }^{4}$ Fish Diseases Department, Animal Health Research Institute AHRI Agriculture Research Centre \\ ARC,Dokki, 12619.Egypt
}

*Corresponding author: ahsherif77@yahoo.com

\section{ARTICLE INFO Article History: \\ Received: Feb. 19, 2021 \\ Accepted: March 30, 2021 \\ Online: April 15, 2021}

Keywords:

Cyprinus carpio;

Aflatoxin;

Cytokine;

Growth Performance;

Aeromonas hydrophila

\section{ABSTRACT}

Aflatoxin $\mathrm{B}_{1}\left(\mathrm{AFB}_{1}\right)$ is an immunosuppressive plant-origin toxin that reduces disease resistance of fish. A total number of 360 fries of the common carp, Cyprinus carpio ( $0.50 \mathrm{~g} /$ fish b.w.) were subdivided into 6 groups $\left(\mathrm{G}_{1}-\mathrm{G}_{6}\right)$. Fish were fed on $\mathrm{AFB}_{1}$-contaminated diet at a dose of 0.5 and $1.0 \mathrm{mg} / \mathrm{kg}$ fish feed in $\mathrm{G}_{2}$ and $\mathrm{G}_{3}$, respectively. $A F B_{1}$-contaminated diet plus nucleotides (NT) supplementation (at $0.2 \%$ instead of normal corn) were $\mathrm{G}_{5}$ and $\mathrm{G}_{6}$, respectively. Fish in $G_{1}$ were fed on diet free from $A F B_{1}$ and NT while in $G_{4}$, fish were fed on diet free from $\mathrm{AFB}_{1}$ and supplemented with NT. Growth performance and liver enzymes (ALT, AST, and ALP) were adversely impacted by feeding on a contaminated diet and NT supplementation could ameliorate such withdraws. Anti-inflammatory IL-10 was increased in groups fed on contaminated diet indicating that inflammation had taken place. Feeding on $\mathrm{AFB}_{1}$-contaminated diets resulted in degenerative changes (hepatic and spleen tissues), NTsupplementation could relieve such changes (low dose of $\mathrm{AFB}_{1}$ ) however impacts of the high dose of $\mathrm{AFB}_{1}$ were severe to a degree that NTsupplementation could not effectively diminish it. Regardless of feeding on contaminated diet, C. carpio supplemented with NT could resist Aeromonas hydrophila infection even those fed on contaminated diets, while unsupplemented groups showed higher mortality rates. A. hydrophila could isolate even after 35 days of experimental infection in C. carpio fed on $\mathrm{AFB}_{1^{-}}$ contaminated diet $\left(\mathrm{G}_{2}\right.$ and $\left.\mathrm{G}_{3}\right)$. It concluded that NT supplementation could ameliorate the adverse health impacts associated with feeding diet contaminated with $\mathrm{AFB}_{1}$ in $C$. carpio.

\section{INTRODUCTION}

Aquaculture is an important participant of the global food supplies, fish and aquatic animal products are among the main sources of dietary protein in many countries worldwide (FAO, 2018). To minimize the costs of aquatic products, fish farmers have 
added plant protein sources (Anater et al. 2016), the excessive usages of plant-based diets raise the potential exposure to aflatoxin B1 (AFB1) which is a foodborne toxin (Hussain et al. 2017). Aflatoxins have serious health hazards causing acute and chronic toxicity, AFB1 are substance with, carcinogenic, genotoxic, and immunosuppressive properties (Flores-Flores et al. 2015). AFB1 toxicity in silver catfish (Rhamdia quelen) associated with many non-specific signs such as immunosuppression, histological lesions, and behavioral changes, and biochemical, haematological, and histopathological parameters were the diagnostic tools to evaluate the health status (Anater et al. 2020; Sherif et al. 2020a). In aquatic experiments conducted on the toxicity of AFB1 in different fish spp, the main signs were gradual declining in growth performance, immune suppression, and fish quality (yellowing of the body surface) (Deng et al. 2010; Mahfouz and Sherif, 2015 and Wang et al. 2016). The susceptibility of fish to AFB1 is depending on several factors such as mycotoxins (type and amount), feeding period, fish (species, sex, age) (Anater et al. 2016). The impact of mycotoxins on fish production still needs to be more clear as it is in livestock (Gonçalves $\boldsymbol{e t}$ al. 2018), also, the efficacy of the ameliorating agents needs to be evaluated before recommendation to the aquatic sector.

Nucleotides (NT) are low molecular weight intracellular compounds (Adenosine monophosphate (AMP), Cytosine monophosphate (CMP), guanosine monophosphate (GM), and uridine monophosphate (UMP)) which play major roles in many of the metabolic processes (Gil, 2002). Since the early 2000s, dietary NT was incorporated in fish feed as a growth promoter, and health enhancer (Huu et al. 2012), immunopromoter (diseases resistant), and gastrointestinal (physiology and morphology) in many aquatic animal species (Burrells $\boldsymbol{e t}$ al. 2001). Several studies stated that adding NT to fish feed enhances the activity of the immune system and growth performance, $0.60 \%$ NT in juvenile hybrid tilapia (Xu et al. 2015), disease-resistant (Aeromonas hydrophila) in zebrafish was occurred by the direct action of the NT (Guo et al. 2019).

So, the purpose of this study was to evaluate the impacts of increasing levels of aflatoxin AFB1 in the fish feed on the immunity of common carp (Cyprinus carpio) fish and the potential role of NT to preserve normal immune status that resists the experimental challenge with $A$. hydrophila bacteria.

\section{MATERIALS AND METHODS}

\section{Experimental Fish:}

To achieve the purpose of the present study, a total of 360 common carp (Cyprinus carpio) fries were obtained from a private local farm in Kafr-Elsheikh, Egypt, with an average body weight of $0.50 \mathrm{~g} /$ fish. Fish were transported in a well-aerated tank to the laboratory of Animal Health Research Institute (AHRI) at Kafr-Elsheikh and then kept in glass aquaria. These aquaria were supplied with chlorine-free tap water. The aquaria were continuously aerated by an electric pump and were held at $28 \pm 2{ }^{\circ} \mathrm{C}$. One third of the water was changed daily. Fish were acclimated for two weeks. During the acclimation period, fish were fed on the basal diet only.

\section{Aflatoxin $\left(\mathrm{AFB}_{1}\right)$ preparation:}

$\mathrm{AFB}_{1}$ was produced through pellets fermentation using Aspergillus parasiticus NRRL 2999 according to the method described by Abdelhamid and Mahmoud (1996). Inclusion rate: 0.5 and $1.0 \mathrm{mg} / \mathrm{kg}$ diet. Determination of $\mathrm{AFB}_{1}$ in ration was carried out 
by quantitative thin layer chromatography TLC following the method described by Eppley (1968).

\section{Supplemented Nucleotides (NT):}

The NT mixture contained $49 \%$ NT $(12 \pm 1 \%$ of Adenosine monophosphate (AMP), $10 \pm 1 \%$ of Cytosine monophosphate (CMP), $16 \pm 1 \%$ of 5 - guanosine monophosphate (GM) and $11 \pm 1 \%$ of uridine monophosphate (UMP), $35 \%$ oligonucleotides, and 10\% water, with the remainder comprised of proteins and polysaccharides. (Nanjing, China) Company: Saccharomyces cerevisiae-originated NT mixture from Biotogether, Batch No.: 2019041601.

Inclusion rate: $0.2 \%$ instead of normal corn.

\section{Experimental Design and Procedure:}

Basal diet was formulated to meet the nutritional requirements of common carp according to NRC (2011). Aflatoxin contaminated corn included in the basal diet instead of normal corn to add the required toxin level. Table (1) shows the physical and chemical composition of the experimental basal diet. The feed ingredients were thoroughly mixed, moisten with warm water $(400 \mathrm{ml} / \mathrm{kg})$ and then cold pressed and extruded to produce $2 \mathrm{~mm}$ pellets. The diets were dried in an air convection oven set at $45{ }^{\circ} \mathrm{C}$. After drying, the diets were stored in airtight bags prior to use.

Table (1): Ingredients composition and chemical analysis of the experimental diet.

\begin{tabular}{|c|c|c|c|c|c|}
\hline \multirow{2}{*}{ Ingredients } & \multicolumn{3}{|c|}{ Aflatoxin Level (mg/kg) } & \multicolumn{2}{|c|}{ Chemical Analysis } \\
\hline & $\mathbf{0 . 0}$ & 0.5 & 1.0 & Moisture\% & 11.09 \\
\hline Corn & 15 & 14.65 & 14.3 & $\mathrm{CP} \%$ & 42.05 \\
\hline Contaminated corn & $\mathbf{0}$ & 0.35 & 0.7 & Ether extract \% & 5.71 \\
\hline Soya $(44 \%)$ & 30 & 30 & 30 & Ash\% & 7.23 \\
\hline Fish meal $(60 \%)$ & 25 & 25 & 25 & Crude fiber $\%$ & 2.63 \\
\hline Wheat flour & 7 & 7 & 7 & NFE $^{4}$ & 35.29 \\
\hline DDGs ${ }^{1}$ & 5 & 5 & 5 & DE (Kcal/Kg) $)^{5}$ & 2954 \\
\hline Corn gluten & 15 & 15 & 15 & & \\
\hline Soya oil & 1.5 & 1.5 & 1.5 & & \\
\hline МCP & 1 & 1 & 1 & & \\
\hline Salt & 0.2 & 0.2 & 0.2 & & \\
\hline Methionine & 0.05 & 0.05 & 0.05 & & \\
\hline Choline chloride & 0.05 & 0.05 & 0.05 & & \\
\hline Mineral premix ${ }^{2}$ & 0.1 & 0.1 & 0.1 & & \\
\hline Vitamin premix ${ }^{3}$ & 0.1 & 0.1 & 0.1 & & \\
\hline
\end{tabular}

${ }^{1}$ DDGs = Dried distilled grains.

${ }^{2}$ Mineral premix: each one kg contain Manganese 60g, Copper $4 \mathrm{~g}$, Zinc 50g, Iodine 1g, iron 80g, Cobalt $0.1 \mathrm{~g}$, Selenium $0.1 \mathrm{~g}$, calcium carbonate $(\mathrm{CaCO} 3)$ carrier to $1000 \mathrm{~g}$.

${ }^{3}$ Vitamin premix: each one Kg contains vitamin A 12000000 IU, vitamin D3 2200000 IU, vitamin E $10 \mathrm{~g}$, vitamin $\mathrm{K} 32 \mathrm{~g}$, vitamin $\mathrm{B}_{1} 1 \mathrm{~g}$, vitamin $\mathrm{B}_{2} 5 \mathrm{~g}$, vitamin $\mathrm{B}_{6} 1.5 \mathrm{~g}$, vitamin $\mathrm{B}_{12} 0.01 \mathrm{~g}$, vitamin $\mathrm{C} 250 \mathrm{~g}$, Niacin $30 \mathrm{~g}$, Biotin $0.050 \mathrm{~g}$, Folic acid $1 \mathrm{~g}$ and Pantothenic acid $10 \mathrm{~g}$ and carrier to $1000 \mathrm{~g}$.

${ }^{4} \mathrm{NFE}=$ Nitrogen free extract.

${ }^{5} \mathrm{DE} \mathrm{Kcal} / \mathrm{kg}=$ Digestible energy (DE) was calculated using formula based on chemical composition of feed stuffs nutrients according to NRC (2011).

Fish were randomly allotted into 6 equal groups (60 fishes per group) of 3 replicates (each aquarium measuring $80 \times 40 \times 40 \mathrm{~cm}$, containing 20 fishes). Table (2) shows the 
applied experimental design. Fish were fed to apparent visual satiation; by hand twice a day at 9:00 and 14:00. Extreme care was taken to assure that all supplied feed was consumed. Fish in each group were weighed at the beginning $\left(\mathrm{W}_{0}\right)$ and then biweekly weighed for a successive period of 8 weeks.

Table (2): Experimental design of fish groups.

\begin{tabular}{|c|c|c|c|c|}
\hline \multirow{2}{*}{ Groups } & \multicolumn{3}{|c|}{ Aflatoxin Level (mg/kg) } & NT supplementation \\
\cline { 2 - 4 } & 0.0 & 0.5 & 1.0 & $(0.2 \%)^{*}$ \\
\hline G1 & -- & -- & -- & -- \\
\hline G2 & -- & + & -- & -- \\
\hline G3 & -- & -- & + & + \\
\hline G5 & -- & -- & -- & + \\
\hline G6 & -- & + & -- & + \\
\hline
\end{tabular}

* NT (Nucleotides) supplemented at $0.2 \%$ instead of normal corn.

\section{Growth performances and feed utilization:}

Total weight gain and weight gain $\%$ were calculated as follows:

\section{Total weight gain $=$ Final body weight- Initial body weight \\ Weight gain $\%=$ Total weight gain/Initial weight $\mathrm{X100}$}

Specific growth rate (SGR) was calculated from the following equation:

Specific Growth Rate $(S G R)=\left(\ln W_{f}-\ln W_{i} \times 100\right) / t$

In $\mathrm{W}_{\mathrm{f}}=$ the natural logarithm of the final weight

In $\mathrm{W}_{\mathrm{i}}=$ the natural logarithm of the initial weight

$\mathrm{t}=$ time (days) between $\ln \mathrm{W}_{\mathrm{f}}$ and $\ln \mathrm{W}_{\mathrm{i}}$

Feed Conversion Ratio (FCR) was calculated for each aquarium as follows:

\section{FCR = Feed intake $/$ total body weight gain}

Protein Efficiency Ratio (PER) was calculated as follows:

\section{PER = Weight gain/Protein intake}

\section{Gene expression of some cytokines of the experimental fish}

To analyze the effect of $\mathrm{AFB}_{1}$ and $\mathrm{NT}$ on gene expression of the proinflammatory cytokines interleukin IL-1 $\beta$ and tumor necrosis factor (TNF)- $\alpha$ and antiinflammatory IL-10, the Reverse Transcription-PCR (RT-PCR) test was performed on tissue of head kidney of C. carpio. All primers are listed in Table (3). The standard TRIzol extraction method (Invitrogen, Paisley, UK) was performed to extract the total RNA from $100 \mu \mathrm{g}$ head kidney of $C$. carpio, RNA were stored at $-80^{\circ} \mathrm{C}$. By using the High-Capacity RNA-to-cDNA Kit (Applied Bio-systems, Carlsbad, CA, USA), $1 \mu \mathrm{g}$ of the obtained RNA was reverse- transcribed into cDNA up to a total of $20 \mu \mathrm{l}$ volume. The collected cDNA was directly used as a template for semi-quantitative PCR. $\beta$-actin amplification is constitutively expressed (Choi et al., 2004) so, it was used as housekeeping gene in semiquantitative RT-PCR. After 19 cycles of amplification, the obtained products were within the linear range of signal amplification and allowed titration of the amount of the template to be subsequently used to obtain consistent 
amounts of products, these products were electrophoretically separated, and on Gel Documentation (UVITEC, UK) the bands were distinguished.

Table (3): The cytokines primers used in the experiment.

\begin{tabular}{|c|l|c|c|c|}
\hline $\begin{array}{c}\text { Primer } \\
\text { name }\end{array}$ & \multicolumn{1}{|c|}{ Direction $\left(\mathbf{5}^{\prime}-\mathbf{3}^{\prime}\right)$} & $\begin{array}{c}\text { Temperature } \\
\left({ }^{\circ} \mathbf{C}\right)\end{array}$ & Size (pb) & Reference \\
\hline IL-1 $\boldsymbol{\beta}$ & $\begin{array}{l}\text { F: GGATTCACAAGAACTAAGGAC } \\
\text { R: ACTGTGATGTACTGCTGAAC }\end{array}$ & 56 for $30 \mathrm{~s}$ & 399 & Zou, et al. $(\mathbf{1 9 9 9})$ \\
\hline IL-10 & $\begin{array}{l}\text { F: ACCCCGTTCGCTTGCCA } \\
\text { R: CATCTGGTGACATCACTC }\end{array}$ & 56 for $30 \mathrm{~s}$ & 70 & $\begin{array}{c}\text { Buonocore } \text { et al. } \\
(\mathbf{2 0 0 7})\end{array}$ \\
\hline TNF- $\boldsymbol{\alpha}$ & $\begin{array}{l}\text { F: AGCATGGAAGACCGTCAACGAT } \\
\text { R: ACCCTCTAAATGGATGGCTGCTT }\end{array}$ & 56 for $30 \mathrm{~s}$ & 131 & $\begin{array}{c}\text { Laing } \text { et al. } \\
(\mathbf{2 0 0 1})\end{array}$ \\
\hline $\boldsymbol{\beta}$-actin & $\begin{array}{l}\text { F: TGGCATCACACCTTCTACAACGA } \\
\text { R: TGGCGGGGGTGTTGAAGGTCT }\end{array}$ & 56 for $30 \mathrm{~s}$ & 139 & Choi et al. (2004) \\
\hline
\end{tabular}

\section{Bacterial infection}

After 8 weeks of feeding trial, fish (40 fish / group) was experimentally exposed to bacterial infection with Aeromonas hydrophila (AHRAS22). Fish was injected intraperitoneal at a dose of $10 \%$ of $\mathrm{LD}_{50}\left(3 \times 10^{5} \mathrm{CFU}\right)$ according to methods reported by Schaperclaus et al. (1992). The number of dead fish was recorded for 14 days, and mortality rate during a specific period (MR) was measured using the following equation:

\section{MR $(\%)=$ number of deaths $/$ total fish number $\times 100$}

After 14 days, the survived fish was bacteriologically examined for A. hydrophila, three attempts of bacterial isolation were performed with a week-interval at days 21,28 , and 35 post-challenge. Bacterial isolation was done using randomly selected five fish from each treatment group and anaesthetized within $60 \mathrm{~s}$ using $50 \mathrm{mg} / \mathrm{l}$ tricaine mesylate. The fish abdomen aseptically opened (sterilized with methyl alcohol 70\%), Specimens were taken from internal organs (Amlacher, 1970) and inoculated into Tryptic soy broth (Difco) and incubated at $28^{\circ} \mathrm{C}$ for $24 \mathrm{hr}$. Then the single pure isolated colonies were stored in cryovials containing $20 \%, 30 \%$ and $50 \%$ glycerol/broth at $-20{ }^{\circ} \mathrm{C}$ for further identification by using API®20 E systems (BioMérieux, Mar-cy I I Etoile, France) (Austin \& Austin (2012).

\section{Liver enzymes:}

The activity of the liver enzymes in the experimental fish, Aspartate Amino Transaminase (AST) and Alanine Amino Transaminase (ALT) were determined in the serum to assess the impact of $\mathrm{AFB}_{1}$ and the ameliorative role of NT according to the methods reported by Reitman \& Frankel (1957). Levels of Alkaline phosphatase (ALP) activity were detected according to methods mentioned by Rec (1972). All kits and reagents were supplied by Diamond Diagnostic Co. 


\section{Histopathological examination:}

Five fish of $C$. carpio from each group were randomly selected for histopathologically examination to detect the alterations in hepatic and splenic tissues. Tissue specimens were fixed with $10 \%$ neutral buffered formalin then processed and stained with haematoxylin and eosin; then examined using an Olympus BX51 light electric microscope according to previously methods described by Roberts (2012).

\section{Statistical Analyses}

To detected the impacts of $\mathrm{AFB}_{1}$ and evaluate the ameliorating role of NT, the obtained results were analysed using SPSS software for windows, SPSS Inc., Chicago, IL, USA (SPSS 2004), analysis of variance (ANOVA). All values were expressed as the mean \pm SE (standard error). At a significance level of 0.05 , the differences among groups were determined by using duncan's multiple range test (Duncan, 1955).

\section{Biosafety measures:}

This study applied biosafety measures according to Pathogen safety data sheets: Infectious substances- A. hydrophila, Pathogen Regulation Directorate (Public Health Agency of Canada, 2010).

\section{RESULTS}

During the experimental period, the water parameter of the tank used showed: Temperature: $28^{\circ} \mathrm{C} \pm 1^{\circ} \mathrm{C}, \mathrm{pH} 7.8$, salinity $\leq 0.3 \mathrm{~g} / \mathrm{I}$, and dissolved oxygen $\geq 5.5 \mathrm{mg} / \mathrm{I}$. The level of $A F B_{1}$, in the experimental diets was $0.5 \mathrm{mg}$ in groups $\mathrm{G}_{2}$ and $\mathrm{G}_{5}$ (with NT) and $1.0 \mathrm{mg}$ in groups $\mathrm{G}_{3}$ and $\mathrm{G}_{6}$ (with NT) while diets of groups $\mathrm{G}_{1}$ free from $\mathrm{AFB}_{1}$ (without NT) and $\mathrm{G}_{4}$ free from $\mathrm{AFB}_{1}$ (with NT).

\section{Clinical and post-mortem examination of Cyprinus carpio:}

C. carpio in the group fed highly contaminated ration $\mathrm{G}_{3}$ suffered from loss of appetite, lethargy, loss of reflexes at the end of the experiment (Fig. 1B). Also, fish showed sluggish swimming, off feed, emaciated fish, dark skin, and loss of reflexes in $\mathrm{G}_{3}$ than any other group. Moreover, fish in $\mathrm{G}_{3}$ after bacterial infection showed dull appearance, emaciated fish (Fig. 1C). On the other hand, the fish in $\mathrm{G}_{4}$ appeared healthy (Fig. 1A). Post examination presented revealed that $C$. carpio in the $\mathrm{G}_{3}$ group which fed on a high $\mathrm{AFB}_{1}$ diet exhibit slight pathological lesion as hepatopancreas discoloration, splenomegaly, and enlarged gall bladder than any other group. There is no change in the internal organs of fish in $\mathrm{G}_{1}$ and $\mathrm{G}_{4}$. 


\section{Effects of dietary aflatoxin on growth of $C$. carpio \\ 2.1. Body weight development:}

The result of body weight development is shown in Table 4. It was noted that the fish started with similar weights, but from the $2^{\text {nd }}$ and $6^{\text {th }}$ weeks control fish group was significantly higher bodyweight than the group fed on basal diet contaminated by aflatoxin $B_{1}$ at level 1.0 or $0.5 \mathrm{mg} / \mathrm{kg}$ diet respectively. Moreover, it was observed that NT supplementation in the fish diet without toxin contamination or with 0.5 and $1.0 \mathrm{mg}$ $\mathrm{AFB}_{1} / \mathrm{kg}$ diet increased final body weight by about $12.5 \%, 16.5 \%$, and $48.9 \%$, respectively, compared to fish group fed on the same diet without NT supplementation (Table 4).

\subsection{Growth performance and feed utilization parameters:}

The total weight gain (TWG), daily weight gain (DWG), gain\%, and specific growth rate (SGR) significantly reduced in the fish groups fed on $\mathrm{AFB}_{1}$ contaminated diet at both concentrations compared to control. Furthermore, feed conversion ratio (FCR) and Protein efficiency ratio (PER) recorded a significant deterioration of fish group fed on $\mathrm{AFB}_{1}$ contaminated diet at both concentrations compared to control (Table 5). Moreover, NT supplementation in the fish diet without toxin contamination insignificantly improved all mentioned parameters compared to the fish group fed on the same diet without NT supplementation, while NT supplementation with $\mathrm{AFB}_{1}$ contaminated diet at both concentrations significantly reduced all mentioned parameters compared to fish groups fed on the same diet without NT supplementation. Significantly improved all mentioned parameters compared to the fish groups fed on the same diet without NT supplementation.

Fig. (1):

(A) C. carpio fed on NT-diets appears healthy.

(B) C.carpio fed on AFB1 intoxicated (G3) showing off feed, emaciated fish and dark skin.

(C) C.carpio fed on AFB1 intoxicated (G3) after bacterial infection, showing dull appearance, emaciated fish (big head)
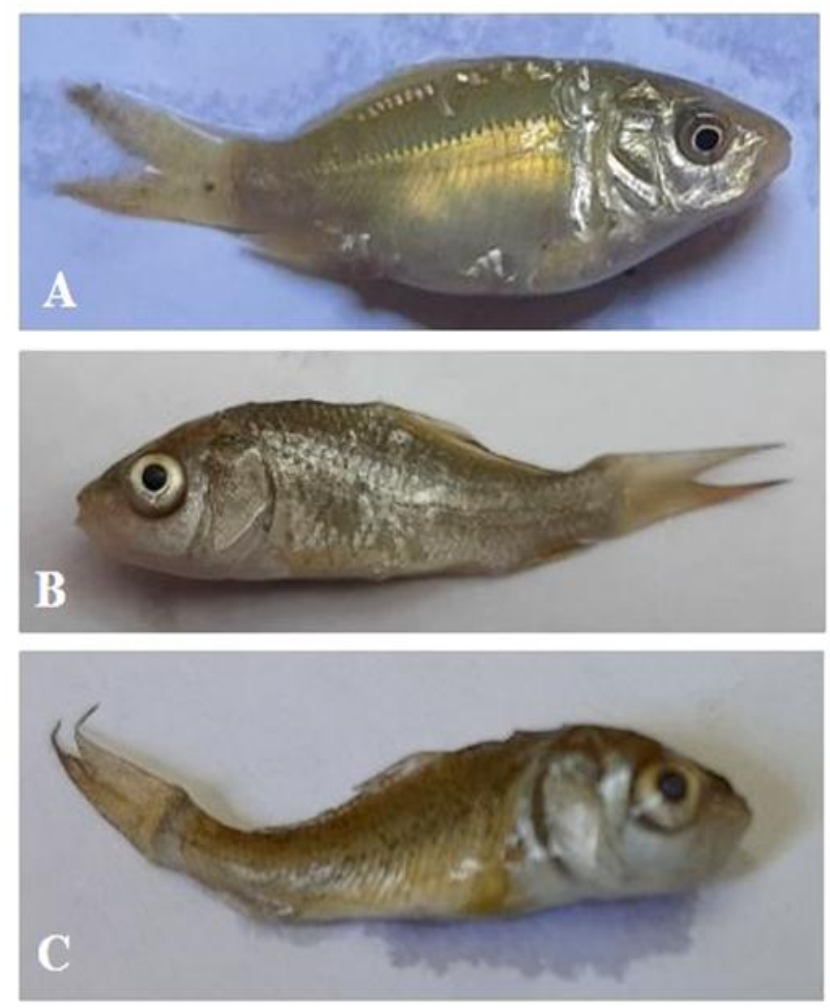
Table(4):Body weight development (g/fish) of $C$. carpio fry as affected by dietary aflatoxin contamination without or with NT supplementation.

\begin{tabular}{|c|c|c|c|c|c|}
\hline \multirow{2}{*}{$\begin{array}{l}\text { Experimental period } \\
\text { (weeks) }\end{array}$} & \multirow{2}{*}{$\begin{array}{c}\text { Dietary aflatoxin } \\
\text { contamination levels }\end{array}$} & \multicolumn{4}{|c|}{ NT supplementation } \\
\hline & & \multicolumn{2}{|r|}{ Without } & \multicolumn{2}{|c|}{ With } \\
\hline $\mathbf{0}$ & $\begin{array}{l}\text { No contamination } \\
0.5 \mathrm{mg} / \mathrm{kg} \text { diet } \\
1.0 \mathrm{mg} / \mathrm{kg} \text { diet }\end{array}$ & $\begin{array}{l}\text { G1 } \\
\text { G2 } \\
\text { G3 }\end{array}$ & $\begin{array}{l}0.49 \pm 0.01^{\text {ax }} \\
0.51 \pm 0.01^{\text {ax }} \\
0.50 \pm 0.01^{\text {ax }}\end{array}$ & $\begin{array}{l}\text { G4 } \\
\text { G5 } \\
\text { G6 }\end{array}$ & $\begin{array}{l}0.50 \pm 0.04^{\mathrm{ax}} \\
0.51 \pm 0.01^{\mathrm{ax}} \\
0.49 \pm 0.01^{\mathrm{ax}}\end{array}$ \\
\hline 2 & $\begin{array}{l}\text { No contamination } \\
0.5 \mathrm{mg} / \mathrm{kg} \text { diet } \\
1.0 \mathrm{mg} / \mathrm{kg} \text { diet }\end{array}$ & $\begin{array}{l}\text { G1 } \\
\text { G2 } \\
\text { G3 }\end{array}$ & $\begin{array}{l}0.74 \pm 0.04^{\text {ax }} \\
0.74 \pm 0.03^{\text {ax }} \\
0.65 \pm 0.01^{\text {by }}\end{array}$ & $\begin{array}{l}\text { G4 } \\
\text { G5 } \\
\text { G6 }\end{array}$ & $\begin{array}{l}0.78 \pm 0.07^{\text {ax }} \\
0.77 \pm 0.03^{\text {ax }} \\
0.69 \pm 0.02^{\text {bx }}\end{array}$ \\
\hline 4 & $\begin{array}{l}\text { No contamination } \\
0.5 \mathrm{mg} / \mathrm{kg} \text { diet } \\
1.0 \mathrm{mg} / \mathrm{kg} \text { diet }\end{array}$ & $\begin{array}{l}\text { G1 } \\
\text { G2 } \\
\text { G3 } \\
\end{array}$ & $\begin{array}{l}1.13 \pm 0.11^{\mathrm{ax}} \\
1.05 \pm 0.04^{\text {ax }} \\
0.84 \pm 0.01^{\text {by }}\end{array}$ & $\begin{array}{l}\text { G4 } \\
\text { G5 } \\
\text { G6 } \\
\end{array}$ & $\begin{array}{l}1.21 \pm 0.13^{\mathrm{ax}} \\
1.14 \pm 0.06^{\mathrm{ax}} \\
0.99 \pm 0.01^{\mathrm{bx}}\end{array}$ \\
\hline 6 & $\begin{array}{l}\text { No contamination } \\
0.5 \mathrm{mg} / \mathrm{kg} \text { diet } \\
1.0 \mathrm{mg} / \mathrm{kg} \text { diet }\end{array}$ & $\begin{array}{l}\text { G1 } \\
\text { G2 } \\
\text { G3 }\end{array}$ & $\begin{array}{l}1.73 \pm 0.14^{\mathrm{ax}} \\
1.49 \pm 0.07^{\mathrm{bx}} \\
1.13 \pm 0.02^{\mathrm{cy}}\end{array}$ & $\begin{array}{l}\text { G4 } \\
\text { G5 } \\
\text { G6 }\end{array}$ & $\begin{array}{l}1.91 \pm 0.20^{\mathrm{ax}} \\
1.67 \pm 0.13^{\mathrm{bx}} \\
1.49 \pm 0.02^{\mathrm{cx}}\end{array}$ \\
\hline 8 & $\begin{array}{l}\text { No contamination } \\
0.5 \mathrm{mg} / \mathrm{kg} \text { diet } \\
1.0 \mathrm{mg} / \mathrm{kg} \text { diet }\end{array}$ & $\begin{array}{l}\text { G1 } \\
\text { G2 } \\
\text { G3 }\end{array}$ & $\begin{array}{l}2.64 \pm 0.25^{\text {ax }} \\
2.12 \pm 0.09^{\text {by }} \\
1.45 \pm 0.03^{\text {cy }}\end{array}$ & $\begin{array}{l}\text { G4 } \\
\text { G5 } \\
\text { G6 }\end{array}$ & $\begin{array}{l}2.97 \pm 0.33^{\mathrm{ax}} \\
2.47 \pm 0.22^{\mathrm{bx}} \\
2.16 \pm 0.07^{\mathrm{cx}}\end{array}$ \\
\hline
\end{tabular}

Data represented as means \pm standard error. Mean values with different letters at the same column (a-c) or row $(x-z)$ and period differ significantly at $(P \leq 0.05)$.

Table(5):Growth performance and feed utilization parameters of $C$. carpio fries as affected by dietary aflatoxin contamination without or with NT supplementation.

\begin{tabular}{|c|c|c|c|c|c|}
\hline \multirow{2}{*}{ Parameters } & \multirow{2}{*}{$\begin{array}{c}\text { Dietary aflatoxin } \\
\text { contamination levels }\end{array}$} & \multicolumn{4}{|c|}{ NT supplementation } \\
\hline & & \multicolumn{2}{|r|}{ Without } & \multicolumn{2}{|r|}{ With } \\
\hline \multirow{3}{*}{$\begin{array}{l}\text { Total weight gain, TWG } \\
\text { (g/fish) }\end{array}$} & No contamination & G1 & $2 . .16 \pm 0.25^{\mathrm{ax}}$ & G4 & $2.47 \pm 0.30^{\mathrm{ax}}$ \\
\hline & $0.5 \mathrm{mg} / \mathrm{kg}$ diet & G2 & $1.61 \pm 0.08^{\text {by }}$ & G5 & $1.96 \pm 0.12^{\mathrm{bx}}$ \\
\hline & $1.0 \mathrm{mg} / \mathrm{kg}$ diet & G3 & $0.96 \pm 0.05^{\mathrm{cy}}$ & G6 & $1.67 \pm 0.08^{\mathrm{cx}}$ \\
\hline \multirow{3}{*}{$\begin{array}{l}\text { Daily weight gain, DWG } \\
\text { (g/fish) }\end{array}$} & No contamination & G1 & $0.039 \pm 0.004^{\mathrm{ax}}$ & G4 & $0.044 \pm 0.004^{\mathrm{ax}}$ \\
\hline & $0.5 \mathrm{mg} / \mathrm{kg}$ diet & G2 & $0.029 \pm 0.003^{\text {by }}$ & G5 & $0.035 \pm 0.003^{b x}$ \\
\hline & $1.0 \mathrm{mg} / \mathrm{kg}$ diet & G3 & $0.017 \pm 0.001^{\mathrm{cy}}$ & G6 & $0.029 \pm 0.001^{\mathrm{cx}}$ \\
\hline \multirow{3}{*}{ Weight Gain \% } & No contamination & G1 & $442.27 \pm 44.88^{\mathrm{ax}}$ & G4 & $500.85 \pm 32.94^{\mathrm{ax}}$ \\
\hline & $0.5 \mathrm{mg} / \mathrm{kg}$ diet & G2 & $312.87 \pm 5.42^{\mathrm{bx}}$ & G5 & $378.70 \pm 26.53^{b x}$ \\
\hline & $1.0 \mathrm{mg} / \mathrm{kg}$ diet & G3 & $193.79 \pm 20.19^{c y}$ & G6 & $345.52 \pm 37.53^{b x}$ \\
\hline \multirow{3}{*}{$\begin{array}{l}\text { Specific growth rate } \\
\text { (SGR) }\end{array}$} & No contamination & G1 & $1.30 \pm 0.06^{\mathrm{ax}}$ & G4 & $1.39 \pm 0.04^{\mathrm{ax}}$ \\
\hline & $0.5 \mathrm{mg} / \mathrm{kg}$ diet & G2 & $1.09 \pm 0.01^{\mathrm{bx}}$ & G5 & $1.21 \pm 0.04^{\mathrm{bx}}$ \\
\hline & $1.0 \mathrm{mg} / \mathrm{kg}$ diet & G3 & $0.83 \pm 0.05^{\mathrm{cy}}$ & G6 & $1.15 \pm 0.06^{\mathrm{bx}}$ \\
\hline \multirow{3}{*}{ Feed intake, FI (g/fish) } & No contamination & G1 & 3.44 & G4 & 3.89 \\
\hline & $0.5 \mathrm{mg} / \mathrm{kg}$ diet & G2 & 3.18 & G5 & 3.44 \\
\hline & $1.0 \mathrm{mg} / \mathrm{kg}$ diet & G3 & 2.62 & G6 & 3.08 \\
\hline \multirow{3}{*}{$\begin{array}{l}\text { Food conversion ratio } \\
\text { (FCR) }\end{array}$} & No contamination & G1 & $1.62 \pm 0.11^{\mathrm{cx}}$ & G4 & $1.49 \pm 0.05^{\mathrm{bx}}$ \\
\hline & $0.5 \mathrm{mg} / \mathrm{kg}$ diet & G2 & $1.98 \pm 0.03^{b x}$ & G5 & $1.78 \pm 0.08^{\mathrm{ax}}$ \\
\hline & $1.0 \mathrm{mg} / \mathrm{kg}$ diet & G3 & $2.76 \pm 0.21^{\mathrm{ax}}$ & G6 & $1.87 \pm 0.14^{\text {ay }}$ \\
\hline \multirow{3}{*}{$\begin{array}{l}\text { Protein efficiency } \\
\text { ratio(PER) }\end{array}$} & No contamination & G1 & $1.63 \pm 0.10^{\mathrm{ax}}$ & G4 & $1.76 \pm 0.06^{\mathrm{ax}}$ \\
\hline & $0.5 \mathrm{mg} / \mathrm{kg}$ diet & G2 & $1.32 \pm 0.02^{\mathrm{ax}}$ & G5 & $1.48 \pm 0.08^{\mathrm{bx}}$ \\
\hline & $1.0 \mathrm{mg} / \mathrm{kg}$ diet & G3 & $0.96 \pm 0.06^{\text {by }}$ & G6 & $1.42 \pm 0.03^{\mathrm{bx}}$ \\
\hline \multirow{3}{*}{$\begin{array}{l}\text { Survival rate, } \mathbf{S R}(\%) \\
(\mathrm{n}=60)\end{array}$} & No contamination & G1 & 91.7 & G4 & 86.7 \\
\hline & $0.5 \mathrm{mg} / \mathrm{kg}$ diet & G2 & 90 & G5 & 91.7 \\
\hline & $1.0 \mathrm{mg} / \mathrm{kg}$ diet & G3 & 83.3 & G6 & 88.3 \\
\hline
\end{tabular}

Data represented as means \pm standard error. Mean values with different letters at the same column (a - c) or row $(x-z)$ and period differ significantly at $(\mathrm{P} \leq 0.05)$. 


\section{Effects of $\mathrm{AFB}_{1}$ and $\mathrm{NT}$ on cytokines gene expression of $\boldsymbol{C}$. carpio}

$\mathrm{AFB}_{1}$ impacted gene expression of pro-inflammatory (IL-1 $\beta$, TNF- $\alpha$ ) and antiinflammatory IL-10 cytokines in the head kidney of $C$. carpio (Table, 6). proinflammatory cytokines showed a declined gene expression with exposure to $\mathrm{AFB}_{1}$ along with a significant increase of anti-inflammatory IL-10 $\left(\mathrm{G}_{3}\right.$ and $\left.\mathrm{G}_{2}\right) 10.3$ and 8.33 fold change, respectively. Compared with control supplementation of NT could ameliorate the immunosuppressive impacts of $\mathrm{AFB}_{1}$ (G5 and G6).

Table (6): Gene expression of cytokines in head kidney of fish

\begin{tabular}{|c|c|c|c|c|c|c|}
\hline Item & $\begin{array}{c}\text { G1 } \\
\text { (Control) }\end{array}$ & $\begin{array}{c}\mathbf{G 2} \\
\left(0.5 \mathrm{mg} \mathrm{AFB}_{1}\right)\end{array}$ & $\begin{array}{c}\text { G3 } \\
(1.0 \mathrm{mg} \\
\left.\mathrm{AFB}_{1}\right)\end{array}$ & $\begin{array}{c}\text { G4 } \\
(\mathrm{NT})\end{array}$ & $\begin{array}{c}\text { G5 } \\
(0.5 \mathrm{mg} \\
\left.\mathrm{AFB}_{1}+\mathrm{NT}\right)\end{array}$ & $\begin{array}{c}\text { G6 } \\
(1.0 \mathrm{mg} \\
\left.\mathrm{AFB}_{1}+\mathrm{NT}\right)\end{array}$ \\
\hline IL1及 & $\begin{array}{l}3.33^{\mathrm{B}} \\
\pm 0.3\end{array}$ & $\begin{aligned} & 2^{\mathrm{C}} \\
\pm & 0.58\end{aligned}$ & $\begin{array}{l}1.67^{\mathrm{C}} \\
\pm 0.33\end{array}$ & $\begin{array}{c}4.67^{\mathrm{A}} \\
\pm .33\end{array}$ & $\begin{array}{l}3.67^{\mathrm{AB}} \\
\pm 0.33\end{array}$ & $\begin{array}{c}3.67^{\mathrm{AB}} \\
\pm 0.3\end{array}$ \\
\hline IL10 & $\begin{array}{l}4.67^{\mathrm{C}} \\
\pm 0.7\end{array}$ & $\begin{array}{c}8.33^{\mathrm{AB}} \\
\pm 0.3\end{array}$ & $\begin{array}{l}10.3^{\mathrm{A}} \\
\pm 0.88\end{array}$ & $\begin{array}{l}4.67^{\mathrm{C}} \\
\pm 0.7\end{array}$ & $\begin{array}{c}6.33^{\mathrm{B}} \\
\pm 0.67\end{array}$ & $\begin{array}{c}8.33^{\mathrm{AB}} \\
\pm 0.3\end{array}$ \\
\hline TNF- $\alpha$ & $\begin{array}{l}7.33^{\mathrm{AB}} \\
\pm 0.67\end{array}$ & $\begin{array}{l}5.67^{\mathrm{CD}} \\
\pm 0.3\end{array}$ & $\begin{array}{l}4.33^{\mathrm{D}} \\
\pm 0.3\end{array}$ & $\begin{array}{l}8.33^{\mathrm{A}} \\
\pm 0.3\end{array}$ & $\begin{aligned} & 7^{\mathrm{B}} \\
\pm & 0.18\end{aligned}$ & $\begin{array}{c}6.67^{\mathrm{BC}} \\
\pm 0.3\end{array}$ \\
\hline
\end{tabular}

Data represented as mean $\pm \mathrm{SE}$ of 3 fish and group with different letters within the same row are significantly different at $\mathbf{P} \leq .05$. IL: interleukin; TNF; tumor necrosis factor.

\section{Effect of dietary aflatoxin on liver enzymes:}

After 12 weeks of fish feeding on $\mathrm{AFB}_{1}$-contaminated diets, the activity of liver enzymes AST, ALT, and ALP were significantly raised in the serum of $C$. carpio in groups $\mathrm{G}_{2}$ and $\mathrm{G}_{3}$ (0.5 and $1.0 \mathrm{mg} \mathrm{AFB}_{1} / \mathrm{kg}$ diets) than $\mathrm{G}_{1}$ (Table 7). By adding the NT in the feed $(0.5$ $\mathrm{g} / \mathrm{kg}$ diet), the levels of ALT, AST, and ALP in the serum of C. carpio of groups $\left(\mathrm{G}_{5}\right.$ and $G_{6}$ ) lowered only in comparison to fish contaminated with $A F B_{1}\left(G_{2}\right.$ and $\left.G_{3}\right)$.

Table (7): Liver enzymes in the experimental $C$. carpio fry.

\begin{tabular}{|c|c|c|c|c|c|c|}
\hline \multirow{2}{*}{ Item } & $\begin{array}{c}\text { G1 } \\
(\text { Control })\end{array}$ & $\begin{array}{c}\text { G2 } \\
(0.5 \mathrm{mg} \\
\left.\mathrm{AFB}_{1}\right)\end{array}$ & $\begin{array}{c}\mathbf{G 3} \\
(1.0 \mathrm{mg} \\
\left.\mathrm{AFB}_{1}\right)\end{array}$ & $\begin{array}{c}\text { G4 } \\
(\mathrm{NT})\end{array}$ & $\begin{array}{c}\text { G5 } \\
(0.5 \mathrm{mg} \\
\left.\mathrm{AFB}_{1}+\mathrm{NT}\right)\end{array}$ & $\begin{array}{c}\text { G6 } \\
(1.0 \mathrm{mg} \\
\left.\mathrm{AFB}_{1}+\mathrm{NT}^{\mathrm{N}}\right)\end{array}$ \\
\hline \multirow{2}{*}{ AST } & $44.67^{\mathrm{D}}$ & $62.3^{\mathrm{C}}$ & $116.7^{\mathrm{A}}$ & $43^{\mathrm{D}}$ & $47^{\mathrm{D}}$ & $88^{\mathrm{B}}$ \\
& \pm 1.76 & \pm 1.45 & \pm 2.6 & \pm 1.7 & \pm 1.7 & \pm 6.8 \\
\hline \multirow{2}{*}{ ALT } & $20.3^{\mathrm{D}}$ & $41.3^{\mathrm{C}}$ & $65.7^{\mathrm{A}}$ & $19.3^{\mathrm{D}}$ & $23.67^{\mathrm{D}}$ & $54.3^{\mathrm{B}}$ \\
& \pm 0.88 & \pm 4.8 & \pm 2.3 & \pm 0.3 & \pm 1.2 & \pm 2.6 \\
\hline \multirow{2}{*}{ ALP } & $25.7^{\mathrm{D}}$ & $29^{\mathrm{C}}$ & $41.7^{\mathrm{A}}$ & $23.7^{\mathrm{D}}$ & $26^{\mathrm{D}}$ & $32^{\mathrm{B}}$ \\
& \pm 1.2 & \pm 2.6 & \pm 1.45 & \pm 0.88 & \pm 2.1 & \pm 1.5 \\
\hline
\end{tabular}

Data represented as mean \pm SE of 3 fish; group with different letters within the same row are significantly different at $\mathbf{P} \leq .05$.

\section{Histopathological examination of $C$. carpio intoxicated with $\mathrm{AFB}_{1}$}

In our study, the sensitivity of $C$. carpio to $\mathrm{AFB}_{1}$, impacts of $\mathrm{AFB}_{1}$ were determined in both hepatic and splenic parenchyma. Hepatic parenchyma in $G_{1}$ revealed normal architecture (Fig. 2A); specimens of $\mathrm{G}_{4}$ fed NT had hepatocytes with more eosinophilic cytoplasm (Fig. 2B). Low-dose $\mathrm{AFB}_{1}\left(\mathrm{G}_{2}\right)$ exhibited the degenerative changes in form of hydropic degeneration (Fig. 2C); admix NT to low-dose $\mathrm{AFB}_{1}\left(\mathrm{G}_{5}\right)$ led to improvement with restoring of hepatocytes to normal appearance (Fig. 2D). More degenerative effect with recorded in high-dose $\mathrm{AFB}_{1}\left(\mathrm{G}_{3}\right)$ in form of severe and massive fatty changes, other area shows emboli (Fig. 2E), admix of NT to high-dose $A_{F B}\left(G_{6}\right)$ relieve (but not) diminish the degenerative effect from intoxicated hepatocytes (Fig. 2F). 
Splenic features detected the normal histopathological character of the fish spleen $\left(\mathrm{G}_{1}\right)$ with presence of melano-macrophage center in (Fig. 3A); NT group $\left(\mathrm{G}_{4}\right)$ indicated to immune stimulation effect in form of multiple melano-macrophage centers (Fig. 3B). Low-dose $\mathrm{AFB}_{1}$ fed $C$. carpio surprisingly indicated the stimulation role in form of a large-sized melano-macrophage center (Fig. 3C), this effect was markedly reduced in low-dose $+\mathrm{NT}$ fed $C$. carpio $\left(\mathrm{G}_{5}\right)$ (Fig. 3D). Meanwhile, high-dose $\mathrm{AFB}_{1}\left(\mathrm{G}_{3}\right)$ markedly inhibited the melano-macrophage center stimulation with minute size (Fig. 3E), admix of NT to high-dose $\mathrm{AFB}_{1}\left(\mathrm{G}_{6}\right)$ moderately improve the melano-macrophage status by restoring it to normal condition (Fig. 3F).
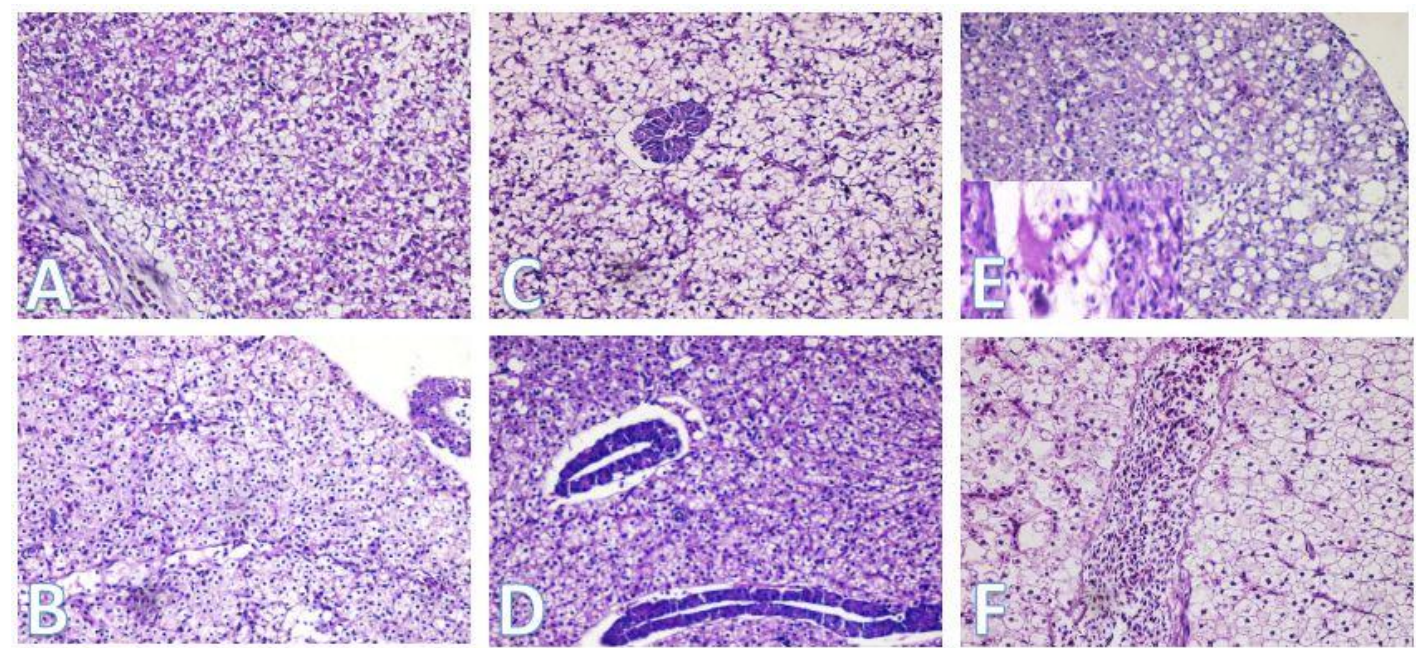

Fig. (2): Microscopic features of hepatic parenchyma in different investigated groups, indicating to normal hepatic character of control negative $\mathrm{G}_{1}(\mathrm{~A})$, more eosinophilic appearance of hepatocytes in $\mathrm{NT}_{4}(\mathrm{~B})$, hydropic degeneration in low-dose $\mathrm{AFB}_{1} \mathrm{G}_{2}(\mathrm{C})$, almost normal hepatocytes in low-dose $\mathrm{AFB}_{1}+\mathrm{NT}_{5}$ (D), marked hepatic degeneration in form of fatty changes in high-dose $A_{F B} G_{3}(E)$, persistence of hepatic degeneration in high dose $\mathrm{AFB}_{1}+\mathrm{NT} \mathrm{G}_{6}(\mathrm{~F}) . \mathrm{H} \& \mathrm{E}$ X 400
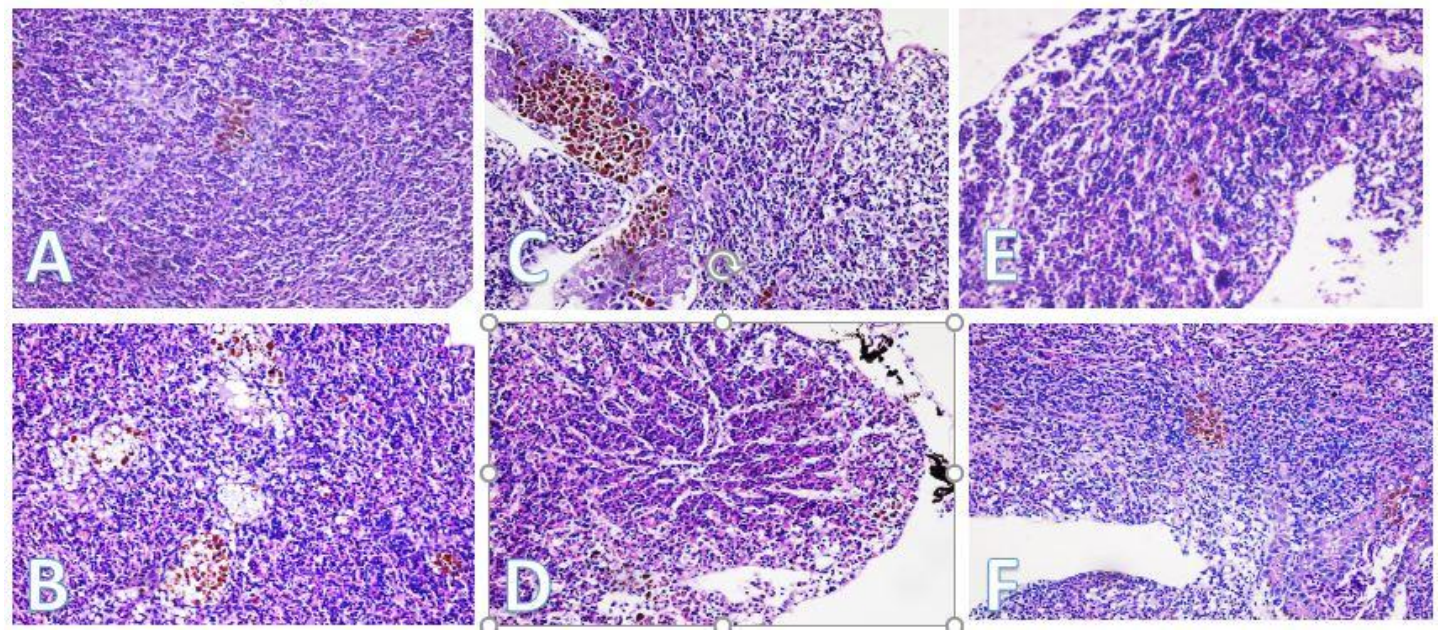

Fig. (3): Microscopic feature of splenic parenchyma in different investigated groups, indicating to normal splenic character of control negative $\mathrm{G}_{1}(\mathrm{~A})$, multiple melano-macrophage centers in NT treated $\mathrm{G}_{4}(\mathrm{~B})$, large -sized melano-macrophage centers in low-dose $\mathrm{AFB}_{1} \mathrm{G}_{2}(\mathrm{C})$, almost absence of melanomacrophage centers in low-dose $\mathrm{AFB}_{1}+\mathrm{NT}_{5}$ (D), marked reduction in the size of melanomacrophage centers in high-dose $\mathrm{AFB}_{1} \mathrm{G}_{3}(\mathrm{E})$, restoring of normal sized melano-macrophage centers of hepatic in high dose $\mathrm{AFB}_{1}+\mathrm{NT} \mathrm{G}_{6}(\mathrm{~F})$. H\&E X 400 


\section{6. $C$. carpio challenged against $A$. hydrophila:}

All six fish groups, after 8 weeks of feeding trial, 40 fish of each group were experimentally infected with A. hydrophila bacteria (Table 8). The ability of $C$. carpio to withstand the $A$. hydrophila showed a lower mortality rate of $7.5 \%$ in a group $\mathrm{G}_{4}$ which fed on $\left(0.5 \mathrm{~g}\right.$ of NT), $15 \%$ in group $\mathrm{G}_{5}$ followed by group $\mathrm{G}_{6}(17.5 \%)$. The highest $\mathrm{MR} \%$ was showed in group $\mathrm{G}_{3}$ then group $\mathrm{G}_{2}$ (35\% and $20 \%$ respectively).

On day 21,28 , and 35 post-challenge 5 survived $C$. carpio were bacteriologically examined for the occurrence of A. hydrophila infection. In Table 9, the presence of bacterial infection decreased and $A$. hydrophila could not be isolated from survived $C$. carpio at the day 35 post-challenge in groups supplemented with NT in diet except for G6 which fed on highly contaminated $\mathrm{AFB}_{1}$ (I out of 5 fish). It was noticed that $C$. carpio intoxicated with $\mathrm{AFB}_{1}$ still harbour $A$. hydrophila.

Table (8): Mortality rate in experimental fish challenged with $A$. hydrophila

\begin{tabular}{|l|c|c|c|c|c|c|}
\hline \multicolumn{1}{|c|}{ Item } & $\begin{array}{c}\text { G1 } \\
(\text { Control })\end{array}$ & $\begin{array}{c}\text { G2 } \\
(0.5 \mathrm{mg} \\
\left.\mathrm{AFB}_{1}\right)\end{array}$ & $\begin{array}{c}\text { G3 } \\
(1.0 \mathrm{mg} \\
\left.\mathrm{AFB}_{1}\right)\end{array}$ & $\begin{array}{c}\text { G4 } \\
(\mathrm{NT})\end{array}$ & $\begin{array}{c}\text { G5 } \\
(0.5 \mathrm{mg} \\
\left.\mathrm{AFB}_{1}+\mathrm{NT}\right)\end{array}$ & $\begin{array}{c}\text { G6 } \\
(1.0 \mathrm{mg} \\
\left.\mathrm{AFB}_{1}+\mathrm{NT}\right)\end{array}$ \\
\hline Challenged & 40 & 40 & 40 & 40 & 40 & 40 \\
\hline Survived & 36 & 32 & 26 & 37 & 36 & 33 \\
\hline Dead & 4 & 8 & 14 & 3 & 4 & 7 \\
\hline MR\% & 10 & 20 & 35 & 7.5 & 15 & 17.5 \\
\hline
\end{tabular}

G: Group; MR: mortality rate.

Table (9).Occurrence of $A$. hydrophila infection in the survived fish post-challenge. $(\mathbf{n}=\mathbf{5})$

\begin{tabular}{|c|c|c|c|c|c|c|}
\hline Item & $\begin{array}{c}\text { G1 } \\
(\text { Control })\end{array}$ & $\begin{array}{c}\text { G2 } \\
(0.5 \mathrm{mg} \\
\left.\mathrm{AFB}_{1}\right)\end{array}$ & $\begin{array}{c}\text { G3 } \\
(1.0 \mathrm{mg} \\
\left.\mathrm{AFB}_{1}\right)\end{array}$ & $\begin{array}{c}\text { G4 } \\
(\mathrm{NT})\end{array}$ & $\begin{array}{c}\text { G5 } \\
(0.5 \mathrm{mg} \\
\left.\mathrm{AFB}_{1}+\mathrm{NT}\right)\end{array}$ & $\begin{array}{c}\text { G6 } \\
(1.0 \mathrm{mg} \\
\left.\mathrm{AFB}_{1}+\mathrm{NT}\right)\end{array}$ \\
\hline Day 21 & 3 & 3 & 3 & 3 & 2 & 2 \\
\hline Day 28 & 1 & 3 & 3 & 0 & 1 & 1 \\
\hline Day 35 & 0 & 2 & 2 & 0 & 0 & 1 \\
\hline
\end{tabular}

\section{DISCUSSION}

Comparing with the control, $C$. carpio in the group fed highly contaminated ration $\mathrm{G}_{3}$ (1.0 mg $\mathrm{AFB}_{1} / \mathrm{kg}$ fish feed) for 60 days suffered from slight clinical and post-mortem lesions. Similar to some extent, fish artificially intoxicated with $\mathrm{AFB}_{1}$ showed a variety of clinical signs such as retarded growth, skin lesions (yellowish discoloration and bleeding), and erratic swimming (El-Sayed and Khalil, 2009 and Mwihia et al., 2018). In accordance, no behavioral alterations were observed that fed gibel carps (Carassius auratus gibelio) fed on $\mathrm{AFB}_{1}$-feed for 24 weeks such as loss of reflexes, sluggish movement, and dyspnea or rapid opercular movements (Huang et al., 2014).

The survival rate of $C$. carpio was badly impacted after 60 days of feeding the contaminated diet $\left(\mathrm{G}_{3}, 83.3 \%\right)$ and was enhanced by the NT supplementation $\left(\mathrm{G}_{6}, 88.3\right)$. Along with the obtained findings, after 12 weeks of exposure to $\mathrm{AFB}_{1}(0,50,100$, and $250 \mu \mathrm{g} / \mathrm{kg}$ ), Gonçalves et al. (2018) observed different survival rates $99.0-99.7 \%$ in catfish, Pangasius hypophthalmus. While, Nile tilapia (freshwater fish) fed on $\mathrm{AFB}_{1^{-}}$ 
contaminated feed $(2000 \mu \mathrm{g} / \mathrm{kg})$ had a survival rate of only $82.2 \%$. According to the results achieved with NT supplementation, Shiau et al. (2015) fed Nile tilapia on diets supplemented with NT ( $\geq 120 \mathrm{mg} / \mathrm{kg}$ diet) had significantly improved survive.

After feeding of $C$. carpio on $\mathrm{AFB}_{1}$-contaminated diets, the growth performance of fish was retarded in $\left(\mathrm{G}_{2}\right.$ and $\left.\mathrm{G}_{3}\right)$ and the NT supplementation could keep normal growth behaviour $\left(\mathrm{G}_{5}\right.$ and $\left.\mathrm{G}_{6}\right)$ compared to the control group $\left(\mathrm{G}_{1}\right)$. Generally, growth parameters gradually decreased when fish were fed on $\mathrm{AFB}_{1}$-diet (Deng et al. 2010). Similarly, a decrease in the final weight, DWG, and FCR in Nile tilapia (Oreochromis niloticus) fed with a diet containing $2000 \mu \mathrm{g} / \mathrm{kg}$ of $\mathrm{AFB}_{1}$ was observed by Ayyat et al. (2018); as well Mahfouz and Sherif (2015) with 20 and $100 \mu \mathrm{g} \mathrm{AFB}_{1} / \mathrm{kg}$ feed for 12 weeks; and also (Lopes et al. 2005) with 41 to $204 \mu \mathrm{g} \mathrm{AFB}_{1} / \mathrm{kg}$ feed in silver catfish for 35 days. Controversy, Anater et al. (2020) conducted a study on different concentrations of dietary $\operatorname{AFB}_{1}(0,45,90$, and $180 \mu \mathrm{g} / \mathrm{kg})$ fed to silver catfish, Rhamdia quelen, they observed that $\mathrm{AFB}_{1}$ did not affect the growth performance linearly.

The improvements of growth parameters obtained in this study after NT supplementation are similar to many previous studies on different fish species. Administration of dietary NT has been reported to enhance the growth of red drum, Sciaenops ocellatus (Li et al. 2007), Caspain brown trout (Kenari et al. 2013), and Beluga sturgeon (Abtahi et al. 2013). Overall, high levels of NT are needed in periods of rapid growth in livestock animals (Carver, 1994). Dissimilar to this study, Shiau et al. (2015) stated that dietary NT supplementation had no growth-promoting effect in juvenile tilapia (0.15-5.1 g body weight). These opposite results could be due to the use of low fish meal $(6 \%)$ diets in their experiment. Also controversy, NT supplementation did not promote the growth of hybrid striped bass (Li et al. 2004), barramundi (Glencross and Rutherford, 2010), channel catfish (Welker et al. 2011) and pikeperch (Jarmolowicz et al., 2012). Different results could be due to fish species and supplementation period.

Pro-inflammatory cytokines (IL- $1 \beta$ and TNF- $\alpha$ ) of the experimental $C$. carpio were significantly impacted with feeding on $\mathrm{AFB}_{1}$ contaminated diet that indicating immunosuppressive status. The decrease of cytokines associated with pro-inflammatory and the increase of anti-inflammatory cytokines could decrease inflammatory responses in fish (Wang and Secombes, 2013; Sherif and Mahfouz, 2019 and Sherif et al. 2020b). Generally, the occurrence of chronic stress could suppress the growth performance (Pickering, 1993). The low dose of $\mathrm{AFB}_{1}$ slightly decrease both mRNA and protein levels of lymphocytic IL-2, IFN $\gamma$ and it preferentially affects macrophage functions as well as IL-1 $\alpha$, IL- 6 , and TNF production by these cells as it decouples the close correlation usually observed between transcriptional and translational controls of IL-1 $\alpha$, IL-6 and TNF production by these cells (Giambrone $\boldsymbol{e t}$ al., 1978 and Dugyala \& Sharma 1996).

In accordance,the silver catfish, Rhamdia quelen fed on $\mathrm{AFB}_{1}$-contaminated feed had hematological and biochemical alterations associated with immunosuppression and hepatoxicity, which are commonly observed with $\mathrm{AFB}_{1}$-exposure in animals (Sahoo et al., 2003 and Anater et al., 2020). On the contrary, Nile tilapia exposed to $\mathrm{AFB}_{1}$ had no significant differences in serum total protein and albumin (Saei et al., 2017).

The present results showed that the supplementation of NT to fish feed could normalize the immune status of $C$. carpio exposed to $\mathrm{AFB}_{1}$ toxicity. Asaduzzaman et al. (2017) reported that gene expression of IGF-1 could be up-regulated in hepatic of Nile 
tilapia which was supplemented with one of the NT (IMP). Accordingly, Shiau et al. (2015) claimed that immune responses and disease resistance of juvenile hybrid tilapia, Oreochromis niloticus $\times$ Oreochromis aureus supplemented at 120-240 mg NT/kg in diet were enhanced as well as survival rate and plasma lysozyme activity. Along with findings of this study, grass carp showed that optimum NT supplementation improved nonspecific immune responses (Tie et al. 2019), Nile tilapia (Ramadan et al., 1994), hybrid striped bass (Li et al. 2004), and red drum, Sciaenops ocellatus (Li et al. 2007).

Aflatoxin detoxification in fish takes place in the hepatopancreas tissue, which is considered to be the main impacted organ (Santacroce $\boldsymbol{e t}$ al., 2008), and liver enzymes including ALT, AST, and ALP activities are good bioindicators for tissue damage and dysfunction (Hassaan et al., 2014). A high level of serum ALP was detected after metabolizing large amounts of toxins by hepatopancreas (Thrall et al. 2007).

After 12 weeks of feeding $\mathrm{AFB}_{1}$, the activity of liver enzymes AST, ALT, and ALP were significantly increased in fish fed on the highly contaminated diet $\left(\mathrm{G}_{3}\right)$ and supplementation with NT resulted in an enhancement that still significantly higher than control $\left(\mathrm{G}_{6}\right)$. The higher activities of ALT and AST in this study are confirmed with those found in Oreochromis mossambicus subjected to $\mathrm{AFB}_{1}$ which alter the integrity of the lysosomal membrane resulting in hepatic impairment (Varior and Philip 2012). These impairments could be assessed by measuring the activity of AST and ALT (Gonçalves $\boldsymbol{e t}$ al. 2018 and Sherif et al. 2020b). Different findings obtained by (Deng et al. 2010) who did not found significant differences in the activities of ALT and AST in Nile tilapia fed on 1,641 $\mu \mathrm{g} \mathrm{AFB}_{1} / \mathrm{kg}$ feed and in Gibel carps fed on diets containing up to $1,000 \mu \mathrm{g}$ $\mathrm{AFB}_{1} / \mathrm{kg}$ feed. Close to the obtained results, Nile tilapia ingested $\mathrm{AFB}_{1}$-contaminated diets 20 and $100 \mu \mathrm{g} \mathrm{AFB} / \mathrm{kg}$ feed for 12 consecutive weeks had a significant increase of AST and ALT (Mahfouz and Sherif, 2015). Disagreeing with the present results, rainbow trout fingerlings exposed to $\mathrm{AFB}_{1}$ recorded insignificant differences in ALP activity (Saei et al. 2017). Furthermore, Shehata et $\boldsymbol{a l}$. (2009) measured AST and ALT in the serum of Nile tilapia fed a diet containing $100 \mu \mathrm{g} / \mathrm{kg}$ of $\mathrm{AFB}_{1}$ and found that enzyme activity had decreased. These differences could be due to aflatoxin has exhausted the hepatic cells along with severe damages of hepatopancreas tissue.

Our results showed improvements in liver condition as the activity of AST, ALT, and ALP were significantly normalized in fish supplemented with NT. Likewise, supplemental NT was found to reduce both ALP and ALT activities in serum of rainbow trout (Tahmasebi-Kohyani et al. 2012), reducing ALP activity as observed in weaned pigs when dietary NT and organic acids were combined (Lee et al. 2007). Variations of liver enzymes were dose-dependent in the plasma of female Nile tilapia (de Lima et al. 2020).

The present study indicated hepatic degeneration in form of hydropic degeneration in the $A F B_{1}$ low-dose group $\left(G_{2}\right)$ that progresses to fatty degeneration in the $\mathrm{AFB}_{1}$ high-dose group $\left(\mathrm{G}_{3}\right)$, this indicated the sensitivity of $C$. carpio to $\mathrm{AFB}_{1}$. In agreement, Al-Azri, et al. (2015) noticed a correlation between the occurrence of vacuolar degeneration to fatty changes in killifish, Aphanius Dispar $\mathrm{AFB}_{1}$ exposure (dose and/or period). Batatinha, et al. (2008) added that these pathological alterations were attributed with biodistribution of $\mathrm{AFB}_{1}$ (via gastrointestinal tract) reaching the hepatic tissue; furthermore, the severity of these alterations was correlated with the dose of $\mathrm{AFB}_{1}$, 
and may led to necrosis via binding of $\mathrm{AFB}_{1}$ metabolites to DNA and RNA of hepatic cells. Other histopathological features were observed; it varied from nuclear and cellular hypertrophy (Chavez-Sanchez et al. 1994) to irregular cords of hepatocytes (large, dark, basophilic with large hyperchromatic nuclei) in rainbow trout (Mwihia et al. 2018). Nucleotides are low molecular weight agents used in clinical nutrition as an exogenous supplement (Carver and Walker, 1995) to improve some physiological functions (Quan, 1992). In this study, improvements of hepatic status were detected in low dose intoxicated group $\left(\mathrm{G}_{5}\right)$, while in high-dose intoxicated fish $\left(\mathrm{G}_{6}\right)$ there was a lower stimulation effect of NT on melano-macrophage centers. The recorded alleviation effect of NT supplementation on $\mathrm{AFB}_{1}$ could be attributed to its ameliorating effect on stress factors (Lin, et al. 2009). NT supplement enhance the anti-oxidant state of the hepatic tissue (Xu, et al. 2015). So, our findings agree with those obtained by Welker $\boldsymbol{e t} \boldsymbol{a l}$. (2011) who claimed that NT has a potential role that could ameliorate the immunosuppressive impacts of stressful factors on the non-specific immunity.

In aquatic pathologists have considered $A$. hydrophila as one of the most fish pathogens causing severe morbidity and high mortalities which accompanied by economic losses (Guo et al. 2019 and Sherif et al. 2020b). In this study, diseases resistance was improved in $C$. carpio received NT could be explained by the findings of Xu et al. (2016) who noted that the growth performance in fish may have been closely related to the infectious diseases resistance, which has been proved to be closely correlated with the immune function in grass carp, Ctenopharyngodon idella. In the present study, fish were subjected to experimental infection with A. hydrophila bacteria, the highest mortality rate $(\%)$ was showed in group $\mathrm{G}_{3}$ then group $\mathrm{G}_{2}(0.5$ and $1 \mathrm{mg}$ of $\mathrm{AFB}_{1}$ respectively). After 21 days post-challenge, survived $C$. carpio still harbour $A$. hydrophila bacteria in groups fed on contaminated $A F B_{1}$-diets $\left(G_{2}\right.$ and $\left.G_{3}\right)$. These findings indicated that fish were immune-compromised and fish are still vulnerable for bacterial infection relapse. Along with our results, Oliveira et al. (2013) noticed a synergistic action between $\mathrm{AFB}_{1}$ and $A$. hydrophila infection in $O$. niloticus fed on $\mathrm{AFB}_{1}$ contaminated diet at $1.177 \mathrm{mg} / \mathrm{kg}$ that survived fish had significant differences with the control group for feed conversion and total length. Fishes fed on an aflatoxinscontaminated diet became vulnerable to stress due to microbial factors such as viruses and bacteria (Rosmaninho et al. 2001 and Lopes et al. 2005). Aflatoxin suppressed both humoral and cell-mediated immune responses; leading to increase vulnerability to secondary bacterial and viral infections which could raise the MR\% in broiler chicks (Yarru et al. 2009).

C. carpio lower mortality rate in a group $\mathrm{G}_{4}$ which fed on the supplemented diet $(0.5 \mathrm{~g} \mathrm{NT})$ and these findings match with the succeeded results of growth parameters and cytokines that showed that $\mathrm{AFB}_{1}$ had dramatically impacted the immune status of $C$. carpio. In accordance, Shiau et al. (2015) found that fish fed on diets supplemented with NT could resist bacterial infection of Streptococcus iniae and survival rate were increased (>80\%) compared with the control group (56.7\%), and in rainbow trout, Oncorhynchus mykiss (Tahmasebi-Kohyani et al. 2011). Similarly, Guo et al. (2019) recorded that zebrafish fed on $0.1 \%$ NT-supplemented diets for 4 weeks could resist $A$. hydrophila NJlinfection; also they explained their findings as dietary NT enhanced the physical barrier and mucosal immunity in the intestine of zebrafish. On the other hand, NT did not alter 
immune response or disease resistance in red drum, Sciaenops ocellatus (Li et al. 2007), these differences could be due to fish species and/or dose-depended.

\section{CONCLUSION}

It is concluded that $C$. carpio is sensitive to $\mathrm{AFB}_{1}$, immune status (cytokines and challenge against $A$. hydrophila) is greatly influenced particularly in fish received a dose of $1 \mathrm{mg} \mathrm{AFB}_{1} / \mathrm{kg}$ fish feed. Despite that fish supplemented NT could restore normal health status, those fed on higher dose of $\mathrm{AFB}_{1}$ dose not fully. Concerning liver enzymes and histopathological features, intoxicated $C$. carpio still harbour A. hydrophila infection even after 35 days post-challenge.

\section{REFERENCES}

Abdelhamid, A.M. and Mahmoud, K.I. (1996). Elimination or adsorption of aflatoxin from poultry feedstuffs. In Proc. Conf. Foodborne contamination \& Egyptian's Health, Mansoura Univ, pp.26-27.

Kenari, A.A.; Mahmoudi, N.; Soltani, M. and Abediankenari, S. (2013). Dietary nucleotide supplements influence the growth, haemato- immunological parameters and stress responses in endangered $\mathrm{C}$ aspian brown trout (Salmo trutta caspius Kessler, 1877). Aquaculture Nutrition, 19(1): 54-63. https://doi.org/10.1111/j. 1365-2095.2012.00938.x

Abtahi, B.; Yousefi, M. and Kenari, A. A. (2013). Influence of dietary nucleotides supplementation on growth, body composition and fatty acid profile of Beluga sturgeon juveniles (Huso huso). Aquaculture Research, 44(2): 254-260.

Al-Azri, H.H.; Ba-Omar, T.; Elshafie, A. and Barry, M.J. (2015). Histopathological and Ultrastructural Changes in the Liver and Gills of the Killifish Aphanius Dispar (Cyprinodontidae) Exposed to Aflatoxin B1. SQU Journal for Science, 20(1): 1-10. https://doi.org/10.1111/j.1365-2109.2011.03028.x

Amlacher, E. (1970). Text Book of Fish Disease (pp. 117-135). New Jersey, USA: T.E.S. publication.

Anater, A.; Araújo, C.M.T.D.; Rocha, D.C.C.; Ostrensky, A.; Engracia Filho, J.R.; Ribeiro, D.R. and Pimpao, C.T. (2020). Evaluation of growth performance, hematological, biochemical and histopathological parameters of Rhamdia quelen fed with a feed artificially contaminated with aflatoxin B1. Aquaculture Reports, 17: 100326. https://doi.org/10.1016/j.aqrep.2020.100326

Anater, A.; Mayes, L.; Meca, G.; Ferrer, E.; Luciano, F.B.; Pimpão, C.T. and Font, G. (2016). Mycotoxins and their consequences in aquaculture: a review. Aquaculture, 451: 1-10. https://doi.org/10.1016/j.aquaculture.2015.08.022

Asaduzzaman, M.; Ikeda, D.; Abol-Munafi, A.B.; Bulbul, M.; Ali, M.E.; Kinoshita, S.; Watabe, S. and Kader, M.A. (2017). Dietary supplementation of inosine monophosphate promotes cellular growth of muscle and upregulates growth-related gene expression in Nile tilapia Oreochromis niloticus. Aquaculture, 468: 297-306. https://doi.org/10.1016/j.aquaculture.2016.10.033 
Austin, B. and Austin, D.A. (2012). Bacterial fish pathogens: Disease of farmed and wild fish, $3^{\text {rd }}$ edition. pp.112-115.

Ayyat, M.S.; Ayyat, A.M.N.; Al-Sagheer, A.A. and El-Hais, A.E.A.M. (2018). Effect of some safe feed additives on growth performance, blood biochemistry, and bioaccumulation of aflatoxin residues of Nile tilapia fed aflatoxin- $\mathrm{B}_{1}$ contaminated diet. Aquaculture, 495: 27-34. https://doi.org/10.1016/j.aquaculture.2018.05.030

Batatinha, M.J.M.; Simas, M.M.S. and Górniak, S.L. (2008). Micotoxicoses. In: Spinosa HS, Górniak SL, Palermo-Neto J., editors. Toxicologia Aplicada à Medicina Veterinária. São Paulo: Manole, pp.479-510.

Buonocore, F.; Randelli, E.; Bird, S.; Secombes, C.J.; Facchiano, A.; Costantini, S. and Scapigliati, G. (2007). Interleukin-10 expression by real-time PCR and homology modelling analysis in the European sea bass (Dicentrarchus labrax L.). Aquaculture, 270(1-4): 512-522. https://doi.org/10.1016/j.aquac ulture.2007. $\underline{05.040}$

Burrells, C.; Williams, P.D. and Forno, P.F. (2001). Dietary nucleotides: a novel supplement in fish feeds: 1. Effects on resistance to disease in salmonids. Aquaculture, 199(1-2): 159-169.

\section{https://doi.org/10.1016/S0044-8486(01)00577-4}

Carver, J. D. (1994). Dietary nucleotides: cellular immune, intestinal and hepatic system effects. The Journal of nutrition, 124(1): 144S-148S.

\section{https://doi.org/10.1093/jn/124.suppl_1.144S}

Carver, J.D. and Walker, W.A. (1995). The role of nucleotides in human nutrition. The Journal of Nutritional Biochemistry, 6(2): 58-72.

https://doi.org/10.1016/0955-2863(94)00019-I

Chavez-Sanchez, M.C.; Palacios, C.M. and Moreno, I.O. (1994). Pathological effects of feeding young Oreochromis niloticus diets supplemented with different levels of aflatoxin $\mathrm{B}_{1}$. Aquaculture, 127(1): 49-60. https://doi.org/10.1016/0044-8486(94) 90191-0

Choi, K.; Law, M.; Harms, C. and Lehman, W. (2004). Hypoxia reperfusion induced immunocompromise of Tilapia (Oreochromis niloticus). Aquatic Animal Health, 19: 128-140. https://doi.org/10.1577/H06-010.1

De Lima, S.A.; Pedreira, A.C.O.; Freitas, J.M.A.; Dalmaso, A.C.S.; Chiella, R.J.; Meurer, F.; Romao, S. and Bombardelli, R.A. (2020). Diets containing purified nucleotides reduce oxidative stress, interfere, with reproduction, and promote growth in Nile tilapia females. Aquaculture, 528. https://doi.org/ 10.1016/j. aquaculture.2020.735509.

Deng, S.X.; Tian, L.X.; Liu, F.J.; Jin, S.J.; Liang, G.Y.; Yang, H. J.; Du, Z.Y. and Liu, Y.J. (2010). Toxic effects and residue of aflatoxin $\mathrm{B}_{1}$ in tilapia (Oreochromis niloticus $\times$ O. aureus) during long-term dietary exposure. Aquaculture, 307(3-4): 233-240. https://doi.org/10.1016/j.aquaculture.2010.07.029

Duncan, D.B. (1955). Multiple range and multiple " $F$ " test. Biometrics 11, 10. 
Dugyala, R.R. and Sharma, R.P. (1996). The effect of aflatoxin $B_{1}$ on cytokine mRNA and corresponding protein levels in peritoneal macrophages and splenic lymphocytes. International journal of immunopharmacology, 18(10): 599-608.

\section{https://doi.org/10.1016/S0192-0561(96)00066-5}

El-Sayed, Y.S. and Khalil, R.H. (2009). Toxicity, biochemical effects and residue of aflatoxin $\mathrm{B}_{1}$ in marine water-reared sea bass (Dicentrarchus labrax L.). Food and chemical toxicology, 47(7): 1606-1609. https://doi.org/10.1016/j.fct.2009.04.008

Eppley, R.M. (1968). Screening Method for Zearalenone., Aflatoxin, and Ochratoxin. Journal of the Association of Official Analytical Chemists, 51(1): 7478. https://doi.org/10.1093/jaoac/51.1.74

FAO (Food and Agriculture Organization) (2018). Global Aquaculture Production Rome, Italy. http:// www.fao.org/fishery/statistics/global-aquaculture- production/ query/en.

Flores-Flores, M.E.; Lizarraga, E.; de Cerain, A.L. and González-Peñas, E. (2015). Presence of mycotoxins in animal milk: A review. Food Control, 53: 163-176. https://doi.org/10.1016/j.foodcont.2015.01.020

Giambrone, J.J.; Ewert, D.L.; Wyatt, R.D. and Eidson, C.S. (1978). Effect of aflatoxin on the humoral and cell-mediated immune systems of the chicken. American Journal of Veterinary Research, 39(2): 305-308.

Gil, A. (2002). Modulation of the immune response mediated by dietary nucleotides. European Journal of Clinical Nutrition, 56(3): S1-S4.

https://doi.org/10.1038/sj.ejcn.1601475

Glencross, B. and Rutherford, N. (2010). Dietary strategies to improve the growth and feed utilization of barramundi, Lates calcarifer under high water temperature conditions. Aquaculture nutrition, 16(4): 343-350.

\section{https://doi.org/10.1111/j.1365-2095.2009.00670.x}

Gonçalves, R.A.; Do Cam, T.; Tri, N.N.; Santos, G.A. and Encarnação, P. (2018). Aflatoxin $\mathrm{B}_{1}\left(\mathrm{AFB}_{1}\right)$ reduces growth performance, physiological response, and disease resistance in Tra catfish (Pangasius hypophthalmus). Aquaculture International, 26(3): 921-936. https://doi.org/10.1007/s10499-018-0259-x

Guo, X.; Li, J.; Ran, C.; Wang, A.; Xie, M.; Xie, Y. and Zhou, Z. (2019). Dietary nucleotides can directly stimulate the immunity of zebrafish independent of the intestinal microbiota. Fish \& shellfish immunology, 86: 1064-1071.

https://doi.org/10.1016/j.fsi.2018.12.058

Hassaan, M.S.; Wafa, M.A.; Soltan, M.A.; Goda, A.S. and Mogheth, N.M.A. (2014). Effect of dietary organic salts on growth, nutrient digestibility, mineral absorption and some biochemical indices of Nile tilapia, Oreochromis niloticus L. fingerlings. World Applied Sciences Journal, 29 (1): 47-55.

Huang, Y.; Han, D.; Xiao, X.; Zhu, X.; Yang, Y.; Jin, J.; Chen, Y. and Xie, S. (2014). Effect of dietary aflatoxin $\mathrm{B}_{1}$ on growth, fecundity and tissue accumulation in gibel 
carp during the stage of gonad development. Aquaculture, 428: 236-242. https://doi.org/10.1016/j.aquaculture.2014.03.010

Hussain, D.; Mateen, A. and Gatlin III, D. M. (2017). Alleviation of aflatoxin B $\left(\mathrm{AFB}_{1}\right)$ toxicity by calcium bentonite clay: Effects on growth performance, condition indices and bioaccumulation of $\mathrm{AFB}_{1}$ residues in Nile tilapia (Oreochromis niloticus). Aquaculture, 475: 8-15. https://doi.org/10.1016/ j. aquaculture. 2017.04.003

Huu, D.H.; Tabrett, S.; Hoffmann, K.; Köppel, P.; Lucas, J.S. and Barnes, A.C. (2012). Dietary nucleotides are semi-essential nutrients for optimal growth of black tiger shrimp (Penaeus monodon). Aquaculture, 366: 115-121.

https://doi.org/10.1016/j.aquaculture.2012.09.007

Jarmolowicz, S.; Zakes, Z.; Siwicki, A.; Kowalska, A.; Hopko, M.; Glabski, E.; Demska-Zakes, K. and Partyka, K. (2012). Effects of brewer's yeast extract on growth performance and health of juvenile pikeperch Sander lucioperca (L.). Aquaculture Nutrition, 18(4): 457-464.

\section{https://doi.org/10.1111/j.1365-2095.2011.00915.x}

Laing, K.J.; Wang, T.; Zou, J.; Holland, J.; Hong, S.; Laing, K.J. and Secombes, C.J. (2001). Cloning and expression analysis of rainbow trout Oncorhynchus mykiss tumour necrosis factor- $\alpha$. European Journal of Biochemistry, 268(5): 13151322.

\section{https://doi.org/10.1046/j.1432-1327.2001.01996.x}

Lee, D.N.; Liu, S.R.; Chen, Y.T.; Wang, R.C.; Lin, S.Y. and Weng, C.F. (2007). Effects of diets supplemented with organic acids and nucleotides on growth, immune responses and digestive tract development in weaned pigs. Journal of animal physiology and animal nutrition, 91(11- 12): 508-518.

\section{https://doi.org/10.1111/j.1439-0396.2007.00684.x}

Li, P.; Gatlin III, D.M. and Neill, W.H. (2007). Dietary supplementation of a purified nucleotide mixture transiently enhanced growth and feed utilization of juvenile red drum, Sciaenops ocellatus. Journal of the World Aquaculture Society, 38(2): 281286. https://doi.org/10.1111/j.1749-7345.2007.00096.x

Li, P.; Lewis, D.H. and Gatlin III, D.M. (2004). Dietary oligonucleotides from yeast RNA influence immune responses and resistance of hybrid striped bass (Morone chrysops $\times$ Morone saxatilis) to Streptococcus iniae infection. Fish \& shellfish immunology, 16(5): 561-569. https://doi.org/10.1016/j.fsi.2003.09.005

Lin, Y.H.; Wang, H. and Shiau, S.Y. (2009). Dietary nucleotide supplementation enhances growth and immune responses of grouper, Epinephelus malabaricus. Aquaculture Nutrition, 15(2): 117-122. https://doi.org/10.1111/ j.1365-2095.2007. 00561.x

Lopes, P.R.S.; Radünz Neto, J.; Mallmann, C.A.; Lazzari, R.; Pedron, F.D.A. and Veiverberg, C.A. (2005). Crescimento e alterações no fígado e na carcaça de alevinos de jundiá alimentados com dietas com aflatoxinas. Pesquisa agropecuária 
brasileira, 40(10): 1029-1034. https://doi.org/10.1590/S0100-204X200500 10000 $\underline{12}$

Mahfouz, M.E. and Sherif, A.H. (2015). A multiparameter investigation into adverse effects of aflatoxin on Oreochromis niloticus health status. J. Basic Appl. Zool., 71: 48-59. https://doi.org/10.1016/j.jobaz.2015.04.008

Mwihia, E.W.; Mbuthia, P.G.; Eriksen, G.S.; Gathumbi, J.K.; Maina, J.G.; Mutoloki, S.; ... and Lyche, J.L. (2018). Occurrence and levels of aflatoxins in fish feeds and their potential effects on fish in Nyeri, Kenya. Toxins, 10(12): 543. https://doi.org/10.3390/toxins10120543

NRC National Research Council. (2011). Nutrient Requirements of Fish and Shrimp. National academies press.

Oliveira, S.T.L.D.; Veneroni-Gouveia, G.; Santurio, J.M. and Costa, M.M.D. (2013). Aeromonas hydrophila em tilápia (Oreochromis niloticus) após a ingestão de aflatoxinas. Arquivos do Instituto Biologico, 80(4): 400-406. https://doi.org 10.1590/ S1808-16572013000400005.

Pickering, A., (1993). Growth and stress in fish production. Aquaculture, 111: 51-63.

Public Health Agency of Canada (2010).The Honourable Leona Aglukkaq, P.C., M.P.

Minister of Health.

Quan, R. (1992). Dietary nucleotides: Potential for immune enhancement. Foods, nutrition and immunity, 1: 13-21.

Ramadan, A.; Afifi, N.A.; Moustafa, M.M. and Samy, A.M. (1994). The effect of ascogen on the immune response of tilapia fish to Aeromonas hydrophila vaccine. Fish \& shellfish immunology, 4(3): 159-165. https://doi.org/ 10. 1006/ fsim.1994.1015

Rec, G.S. (1972). Determination of alkaline phosphatase. Journal of Clinical Chemistry \& Clincal Biochemistry, 10: 82.

Reitman, S. and Frankel, S. (1957). Determination of AST and ALT in serum. American Journal of Clinical Pathology, 28: 56-68.

Roberts, R. J. (2012). Fish Pathology $\left(4^{\text {th }}\right.$ ed.). W.B. Saunders, An imprint of Harcourt Publishers.

Rosmaninho, J.F.; Oliveira, C.A.F. and Bittencourt, A.B.F. (2001). Efeitos das micotoxicoses crônicas na produção avícola. Arquivos do Instituto de Biologia, 68(2): 107-114.

Saei, M.M.; Taee, H.M.; Siahpoust, S. and Taheri, M. (2017). Effects of toxin binder biotox on growth performance survival, enzymatic activity, Hematologichal and biochemical parameters of fingerlings rainbow trout (Oncorhynchus mykiss) fed diets-contaminated with aflatoxin. J. Aquac. Res. Development, S2-013. doi, 10, 2155-9546.

Sahoo, P.K.; Mukherjee, S.C.; Jain, A.K. and Mukherjee, A. (2003). Histopathological and electron microscopic studies of gills and opisthonephros of 
rohu, Labeo rohita to acute and subchronic aflatoxin $\mathrm{B}_{1}$ Toxicity. Asian Fisheries Science, 16(3/4): 257-268.

Santacroce, M.P.; Conversano, M.C.; Casalino, E.; Lai, O.; Zizzadoro, C.; Centoducati, G. and Crescenzo, G. (2008). Aflatoxins in aquatic species: metabolism, toxicity and perspectives. Reviews in Fish Biology and Fisheries, 18(1): 99-130.

Schaperclaus, W.; Kulow, H., and Schreckenbach, K. (1992). Fish disease. Rotterdam, the Netherlands: A.A. Balkema,101-105.

Shehata, S.A.; El-Melegy, K.M. and Ebrahim, M.S. (2009). Toxicity reduction of aflatoxin $B_{1}$ by vitamin $C$ in fish. Journal of Arabian Aquaclture Society, 4: 73-86.

Sherif, A. H., Gouda, M. Y., Al-Sokary, E. T., and Elseify, M. M. (2020)a. Lactobacillus plantarum enhances immunity of Nile tilapia Oreochromis niloticus challenged with Edwardsiella tarda. Aquaculture Research, 52(3), 1001-1012. https://doi.org/10.1111/are.14955

Sherif, A.H. and Mahfouz, M.E. (2019). Immune status of Oreochromis niloticus experimentally infected with Aeromonas hydrophila following feeding with 1, $3 \beta$ glucan and levamisole immunostimulants. Aquaculture, 509: 40-46.

https://doi.org/10.1016/j.aquaculture.2019.05.016

Sherif, A.H.; Gouda, M.Y.; Naena, N.A. and Ali, A.H. (2020)b. Alternate weekly exchanges of feeding regime affect the diversity of intestinal microbiota and immune status of Nile tilapia Oreochromis niloticus. Aquaculture Research, 51(10): 4327-4339. https://doi.org/10.1111/are.14778

Shiau, S.Y.; Gabaudan, J. and Lin, Y.H. (2015). Dietary nucleotide supplementation enhances immune responses and survival to Streptococcus iniae in hybrid tilapia fed diet containing low fish meal. Aquaculture Reports, 2, 77-81. https://doi.org/10.1016/j.aqrep.2015.08.002

Tahmasebi-Kohyani, A.; Keyvanshokooh, S.; Nematollahi, A.; Mahmoudi, N. and Pasha-Zanoosi, H. (2011). Dietary administration of nucleotides to enhance growth, humoral immune responses, and disease resistance of the rainbow trout (Oncorhynchus mykiss) fingerlings. Fish \& shellfish immunology, 30(1): 189-193.

https://doi.org/10.1016/j.fsi.2010.10.005

Tahmasebi-Kohyani, A.; Keyvanshokooh, S.; Nematollahi, A.; Mahmoudi, N. and Pasha-Zanoosi, H. (2012). Effects of dietary nucleotides supplementation on rainbow trout (Oncorhynchus mykiss) performance and acute stress response. Fish Physiology and Biochemistry, 38(2):431-440. https://doi.org/10.1007/s10695-0119524-x

Thrall, M.A.; Baker, D.C.; Campbell, T.W.; Denicola, D.; Fettman, M.J.; Lassen, E.D.; Rebar, A. and Weiser, G. (2007). Hematologia e Bioquímica Clínica Veterinária. Editora Roca, São Paulo.

Tie, H.M.; Wu, P.; Jiang, W.D.; Liu, Y.; Kuang, S.Y.; Zeng, Y.Y.; Jiang, J.; Tang, L.; Zhou, X.Q. and Feng, L. (2019). Dietary nucleotides supplementation affects 
the physicochemical properties, amino acid and fatty acid constituents, apoptosis and antioxidant mechanisms in grass carp (Ctenopharyngodon idella) muscle. Aquaculture, 502: 312-325. https://doi.org/10.1016/j.aquaculture. 2018. $\underline{12.045}$

Varior, S. and Philip, B. (2012). Aflatoxin $\mathrm{B}_{1}$ induced alterations in the stability of the lysosomal membrane in Oreochromis mossambicus (Peters, 1852). Aquaculture Research, 43(8): 1170-1175. https://doi.org/10.1111/j.1365-2109.2011.02920.x

Wang, T. and Secombes, C.J. (2013). The cytokine networks of adaptive immunity in fish. Fish \& shellfish immunology, 35(6): 1703-1718.

https://doi.org/10.1016/j.fsi.2013.08.030

Wang, X.; Wang, Y.; Li, Y.; Huang, M.; Gao, Y.; Xue, X.; Zhang, H.; Encarnacao, P.; Santos, G. and Goncalves, R.A. (2016). Response of yellow catfish (Pelteobagrus fulvidraco) to different dietary concentrations of aflatoxin B1 and evaluation of an aflatoxin binder in offsetting its negative effects. Ciencias marinas, 42(1), 15-29. https://doi.org/10.7773/cm.v42i1.2595

Welker, T.L.; Lim, C.; Yildirim- Aksoy, M. and Klesius, P.H. (2011). Effects of dietary supplementation of a purified nucleotide mixture on immune function and disease and stress resistance in channel catfish, Ictalurus punctatus. Aquaculture Research, 42(12): 1878-1889. https://doi.org/10.1111/j.1365-2109.2010.02794.x

Xu, H.J.; Jiang, W.D.; Feng, L.; Liu, Y.; Wu, P.; Jiang, J.; Kuang, S.Y.; Tang, L.; Tang, W.N. and Zhou, X.Q. (2016). Dietary vitamin C deficiency depresses the growth, head kidney and spleen immunity and structural integrity by regulating NF$\kappa \mathrm{B}$, TOR, Nrf2, apoptosis and MLCK signaling in young grass carp (Ctenopharyngodon idella). Fish \& shellfish immunology, 52: 111-138. https://doi.org/10.1016/j.fsi.2016.02.033

Xu, L.; Ran, C.; He, S.; Zhang, J.; Hu, J.; Yang, Y.; ... and Zhou, Z. (2015). Effects of dietary yeast nucleotides on growth, non-specific immunity, intestine growth and intestinal microbiota of juvenile hybrid tilapia Oreochromis niloticus $\rho^{x}$

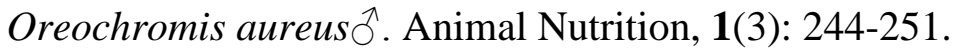

https://doi.org/10.1016/j.aninu.2015.08.006

Yarru, L.P.; Settivari, R.S.; Antoniou, E.; Ledoux, D.R. and Rottinghaus, G.E. (2009). Toxicological and gene expression analysis of the impact of aflatoxin $B_{1}$ on hepatic function of male broiler chicks. Poultry Science, 88(2): 360-371.

https://doi.org/10.3382/ps.2008-00258

Zou, J.; Grabowski, P.S.; Cunningham, C. and Secombes, C.J. (1999). Molecular cloning of rainbow trout Oncorhynchus mykiss interleukin $1 \beta$ reveals no evidence of an ICE cut site. Cytokine, 11: 552-560. 